Article

\title{
Social-LCA. Methodological Proposal Applied to Physical Activity Program Implementation into Old People's Routines
}

\author{
Francisco Javier Flor-Montalvo ${ }^{1}$, Jorge Luis García-Alcaraz ${ }^{2}{ }^{\circledR}$, \\ Agustín Sánchez-Toledo Ledesma ${ }^{1}$ and Leandro Álvarez-Kurogi ${ }^{3, * \mathbb{C}}$ \\ 1 Higher School of Engineering and Technology, International University of La Rioja (UNIR), \\ 26004 Logroño, Spain; franciscojavier.flor@unir.net (F.J.F.-M.); agustin.sancheztoledo@unir.net (A.S.-T.L.) \\ 2 Department of Industrial Engineering and Manufacturing, Autonomous University of Ciudad Juarez, \\ Ciudad Juárez 32315, CUU, Mexico; jorge.garcia@uacj.mx \\ 3 Education Faculty, International University of La Rioja (UNIR), 26004 Logroño, Spain \\ * Correspondence: leandro.alvarez@unir.net; Tel.: +34-640-522-344
}

Received: 29 April 2020; Accepted: 10 June 2020; Published: 18 June 2020

check for updates

\begin{abstract}
Progressive population aging and life expectancy increase in Spain, resulting from medical and social improvements, have put this population segment in a privileged position for the implementation of new methodologies aimed at improving the quality of life of the elderly. Social life cycle analysis (S-LCA) is a widely studied technique to evaluate the social and environmental impacts generated by a product, service, or process. Throughout this paper, S-LCA is applied to the implementation of physical activity programs in routines for older people, allowing a complete evaluation of the impact of such activities. From this study, it is deduced that the execution phase of the program is the one that causes the most positive impact. Design and programming have a much more notable impact than expected. With regard to the involved categories, the user is the greatest beneficiary of the implementation of these programs, although the local community and administration are other interest groups that will highly benefit, although the impact will be much less than in the case of users.
\end{abstract}

Keywords: social assessment; social sustainability; elderly; physical activity; social life cycle analysis (S-LCA)

\section{Introduction}

Throughout the 20th century, there have been significant demographic changes resulting from medical and social improvements, as well as cultural changes. While at the beginning of the 20th century, the population over 65 years old was less than $5.3 \%$, in the 1970 s, it reached $10 \%$, and it is now close to $16 \%$. These data place Spain as the fourth oldest country in the world, although it is the second oldest in terms of population aging [1]. It should also be noted that the group with the highest level of sedentariness is between 65 and 74 years of age.

In terms of gender, males are the most sedentary in all age groups, except for those aged 45-64 years. It is also important to note that this difference increases with age.

We are currently in a transition period, during which the population will age progressively and especially from 2020, with a forecast of $1.2 \%$ of the population over 65 years, which will place the population of elderly people above 2.4 million by 2040 [1].

Population structure associated with nationality analysis shows that the percentage of people aged between 0 and 15 years is similar for national and foreign populations, with a percentage of around $16 \%$. In foreign populations, 16 to 29 -year-old people assume a much higher percentage of the 
total population than in the Spanish population for the same age group, with percentages of $19 \%$ and $14 \%$, respectively. The analysis of age groups between 30 and 44 years also shows a greater impact on foreign populations, with $32 \%$ compared to the national population of $29 \%$. This trend changes with the higher ages, where the percentage of people over 45 and, especially over 65, is much higher in the case of the Spanish population, with respect to foreign populations, as we can deduct from Table 1.

Table 1. Segmentation of the population in Spain by age group [1].

\begin{tabular}{cccc}
\hline & 1 January 2018 & 1 January 2017 & 1 January 2016 \\
\hline Total population & $46,733,038$ & $46,658,447$ & $46,527,039$ \\
0 to15 years $(\%)$ & 15.9 & 16.0 & 16.1 \\
\hline 16 to 64 years $(\%)$ & 64.9 & 65.0 & 65.2 \\
\hline 65 years and over $(\%)$ & 19.2 & 19.0 & 18.7 \\
\hline Dependency rate & 29.6 & 29.2 & 28.7 \\
National population & $42,095,485$ & $42,107,583$ & $42,022,582$ \\
Percentage of total & 90.2 & 90.5 & 90.5 \\
0 to 15 years (\%) & 16.0 & 16.1 & 16.2 \\
16 to 64 years $(\%)$ & 63.7 & 63.8 & 64.0 \\
65 years and over $(\%)$ & 20.4 & 20.1 & 31.0 \\
Dependency rate & 32.0 & 31.4 & $4,417,517$ \\
Foreing population & $4,562,962$ & $4,419,456$ & 9.5 \\
Percentage of total & 9.8 & 9.5 & 15.5 \\
0 to 15 years $(\%)$ & 15.7 & 15.5 & 76.6 \\
\hline 16 to 64 years $(\%)$ & 75.9 & 76.1 & 8.0 \\
\hline 65 years and over $(\%)$ & 8.4 & 8.4 & 10.4 \\
\hline Dependency rate & 11.0 & 11.0 & \\
\hline
\end{tabular}

An analysis of the evolution of the average age throughout the present 21st century shows progressive aging of the population from almost 40 years of average age in 2012 to almost 43 years of average age in 2018.

Although the progression of this average age has grown steadily among the Spanish population, it is interesting to show how it has grown most notably among foreign populations for which, in the period defined, this average age has gone from 32 years in 2014 to over 36 years in 2018 [1].

\subsection{Health in the Elderly}

According to the World Health Organization (WHO) definition, "health is a state of complete physical, mental and social well-being and not merely the absence of disease or infirmity". The quotation comes from the preamble of the Constitution of the WHO and was later adopted by the International Health Conference in New York in 1946, entering into force in April 1948 and remaining unchanged until today.

The health of an individual depends on several aspects that we will divide into mental health, physical health, and psycho-affective health.

Mental health refers to the neuronal degradation derived from the aging process itself and the consequent progressive disappearance of neuronal and cerebral tissue.

Taking into account this circumstance, physical activity helps to prevent and minimize this loss through the processes of memorization and centering of attention derived from the physical exercise itself, and especially from the memorization of movements and dance steps [2].

On the other hand, and taking into account physical health, as a high age is reached, a series of effects are produced on the individual, including a decrease in skin elasticity, nail fragility, hair loss, muscle contraction problems, loss of bone mineralization, joint degeneration, loss of sight, hearing loss, decrease in the number of taste buds, reduction of lung and heart capacity, or slowness in 
sensory-motor functions, among other effects [2,3]. In this way, the inclusion of physical exercise routines can help to minimize the effects of aging while promoting the conservation of motor, cardiac, pulmonary, and motor functions.

Other factors, such as diet, have a great influence on the state and perception of health. In addition, the Mediterranean diet has an important influence on the state of health [4].

Finally, with respect to psycho-affective processes, the effects of physical activity will help, in all age ranges, to reduce levels of depression and anxiety, improve tolerance to stress, and increase the quality of life $[5,6]$.

All these effects should be considered, as the limitation of activity and autonomy of the individual, generated by the circumstances cited above, considerably affect the individual's quality of life $[7,8]$.

From Table 2, it can be deduced how the functional dependence for the accomplishment of daily tasks in people over 65 years old is more notable in women than in men.

Table 2. Daily activities difficulties segregated by gender [9].

\begin{tabular}{cccccc}
\hline & Clean up & Dressing & Getting up or Sitting Down & Going to the Toilet & Feeding \\
\hline Total $(\%)$ & 17.3 & 14.0 & 13.8 & 9.9 & 5.4 \\
Men $(\%)$ & 11.7 & 11.0 & 9.8 & 7.2 & 4.6 \\
Women $(\%)$ & 21.6 & 16.3 & 16.9 & 12.0 & 6.0 \\
\hline
\end{tabular}

It should also be noted that the activities with the greatest difficulty for those over 65 are those of washing, dressing, getting up and sitting down, and eating, which, in all cases, considerably affect the personal autonomy of elderly people.

\subsection{Perception of Health Status in Older People}

The analysis of the perception of their health conditions for older persons in Spain shows that $70.99 \%$ evaluate their state of health as good or very good, $20.51 \%$ as fair, and $8.5 \%$ as bad or very bad [10].

From the detailed analysis of the perception of their state of health according to age and sex, it can be appreciated how, for those over 65 years old, the perception of their state of health as bad or very bad is worse in the case of women for all age groups.

However, it is remarkable how, as Table 3 shows, in all cases, this perception worsens as the years go by and especially after the age of 74 .

Table 3. Assessment of the perceived state of health segmented by gender and age [9].

\begin{tabular}{ccccccccccc}
\hline & Very & Good & Good & $\begin{array}{c}\text { Medium } \\
\text { Med }\end{array}$ & Bad & $\begin{array}{c}\text { Very } \\
\text { Bad }\end{array}$ & $\begin{array}{c}\text { Very } \\
\text { Good }\end{array}$ & Good & $\begin{array}{c}\text { Women } \\
\text { Medium }\end{array}$ & $\begin{array}{c}\text { Very } \\
\text { Bad }\end{array}$ \\
\hline Total (\%) & 28.4 & 49.4 & 16.6 & 4.4 & 1.3 & 25 & 45.5 & 21 & 6.5 & 2 \\
\hline from 15 to 24 years (\%) & 46.2 & 47.7 & 4.8 & 1 & 0.4 & 39.3 & 48.6 & 10.4 & 1.6 & 0.2 \\
from 25 to 34 years (\%) & 40.5 & 49.7 & 8.1 & 1.6 & 0.3 & 32.8 & 51.2 & 13.7 & 2 & 0.4 \\
from 35 to 44 years (\%) & 27.7 & 55.5 & 13 & 3.2 & 0.6 & 24.3 & 54.1 & 17.7 & 2.8 & 1.1 \\
from 45 to 54 years (\%) & 19.1 & 56.5 & 18.3 & 4.9 & 1.2 & 16.6 & 53.2 & 22.5 & 5.7 & 2.1 \\
from 55 to 64 years (\%) & 11.1 & 51.2 & 27 & 8.1 & 2.6 & 10.6 & 48.1 & 28.4 & 9.5 & 3.5 \\
from 65 to 74 years (\%) & 9.1 & 52.5 & 28.9 & 7.6 & 2 & 7.8 & 40.8 & 34.8 & 13.7 & 3 \\
from 75 to 84 years (\%) & 4.5 & 38.1 & 40.5 & 12.3 & 4.6 & 4 & 28.4 & 41.1 & 20.3 & 6.3 \\
85 and older (\%) & 3.3 & 31.2 & 42.7 & 16.9 & 5.9 & 4.4 & 26.9 & 39.8 & 21.2 & 7.7 \\
\hline
\end{tabular}

An analysis of the most frequent chronic illnesses in adult people shows how these diseases, including hypertension, hypercholesterolemia, as well as back and neck pain, are linked to, among other factors, the lack of physical exercise, as we can see in Table 4.

The influence of a sedentary lifestyle, depending on age, stands out. With the only exception of the first years of life, in which a sedentary lifestyle is associated with the inability of the individual to 
perform physical exercise, we can see how the impact of a sedentary lifestyle increases progressively with age, although, from the age of 45 , this trend stabilizes to rise again in older ages.

Table 4. Percentage of people aged 15 and over affected by the most common ailments and diseases [9].

\begin{tabular}{ccccccc}
\hline & Hypertension & Low Back Pain & Cholesterol & Osteoarthritis & Cervical Pain & Allergy \\
\hline Total & 18.4 & 17.3 & 16.5 & 16.4 & 14.7 & 13.4 \\
Men & 18.0 & 13.8 & 15.7 & 10.4 & 9.3 & 11.3 \\
Women & 18.8 & 20.8 & 17.2 & 22.1 & 19.9 & 15.4 \\
\hline
\end{tabular}

It is interesting to contrast the perception of the health of individuals and their levels of sedentary lifestyle to be able to appreciate a direct relationship between both.

From the analysis of the previous data provided in Table 5, it can be deduced that, from the age of 65 onwards, sedentary lifestyles grow, promoting the appearance of different health conditions and considerably reducing the perfection of well-being, as well as the self-esteem and self-perception of the elderly.

Table 5. Percentage of sedentarism by age groups and sex [9].

\begin{tabular}{ccccc}
\hline & \multicolumn{2}{c}{ Men } & \multicolumn{2}{c}{ Women } \\
\hline & Yes & No & Yes & No \\
\hline Total & 31.9 & 68.1 & 40 & 60 \\
\hline from 0 to 4 years (\%) & 52.9 & 47.1 & 55 & 45 \\
from 5 to 14 years (\%) & 10.8 & 89.2 & 17.4 & 82.6 \\
from 15 to 24 years (\%) & 23.2 & 76.8 & 37.2 & 62.8 \\
from 25 to 4 years (\%) & 29.3 & 70.7 & 39.9 & 60.1 \\
from 35 to 44 years (\%) & 34.9 & 65.1 & 43.2 & 56.8 \\
from 45 to 54 years (\%) & 39.1 & 60.9 & 35.2 & 64.8 \\
from 55 to 64 years (\%) & 34.4 & 65.6 & 37.2 & 62.9 \\
from 65 to 74 years (\%) & 28.9 & 71.1 & 38.8 & 61.2 \\
from 75 to 84 years (\%) & 38.6 & 61.5 & 58.7 & 41.3 \\
85 and older (\%) & 58.7 & 41.3 & 76.2 & 23.8 \\
\hline
\end{tabular}

On the other hand, gender is not a determining factor, as age and the appearance of sedentariness are associated with increasing age.

If we consider the progressive aging of the population, together with the previously exposed deterioration of health associated with age, it is estimated that the implementation of exercise programs for adults can have a considerable impact both on the perception and the state of health of the users of such programs, as well as on many other interest groups, such as their families, caregivers or even the State itself.

\subsection{Life Cycle Analysis vs. Social Life Cycle Analysis}

Life cycle analysis (LCA) is one of the techniques widely used to identify and quantify the environmental impacts of products, processes, or services.

The origin of life cycle analysis dates back to the end of the 1960s. During the 1970s, it was already being used as a decision-making element for companies and other decision-making bodies, helping them to understand the different impacts of their products and especially those of the packaging of the product.

This methodology can be used for the analysis of products in very different sectors, such as the agri-food, industrial, or energy sectors [11,12].

This methodology is useful for examining the life cycle of the product since it identifies and quantifies the impacts based on the flows of input and output materials, energy consumption, the dedication of labor, and the rest of the factors that intervene in the process [13,14]. 
This methodology is widely used to identify and quantify environmental loads during the manufacturing and life cycle of a product, in addition to allowing the proposal, simulation, and validation of alternative scenarios to mitigate environmental impacts, providing the quantitative basis for evaluating and choosing alternatives for improving the environmental performance of a system throughout its life cycle $[15,16]$.

However, this methodology has some obvious limitations derived from its own field of application and which consist of the fact that they are not capable of analyzing the impacts on the different agents in society given that it is limited to the environmental impacts of the service, product, or process, both during its manufacturing process and throughout its useful life, facilitating the obtaining of information and decision-making [17,18] and environmental sustainability [19-22].

In these circumstances, the social life cycle analysis (S-LCA) arises.

An S-LCA, like the environmental LCA, analyses the impacts of a certain service, product, or process on its environment and on all the actors involved. However, in the case of the S-LCA, its objective extends to the assessment of these services, products, or processes, and the potential social impacts of the same, both positive and negative, throughout their life cycles [23,24].

In this way, we could define social life analysis as the technique of evaluation of social impact, both real and potential, which has as its objective the evaluation of social and socioeconomic aspects of services, processes, or products and the effect, both positive and negative, that they originate throughout their life cycles.

In this way, an S-LCA is a complement to the environmental LCA, in which the social and socioeconomic aspects are included and can be applied alone or in combination with the LCA-A.

The S-LCA will evaluate the social and socioeconomic impacts throughout the entire life cycle, including both the supply chain and use and disposal with generic and site-specific information.

Its main differences with respect to other social impact assessment techniques lie in its objectives corresponding to products, processes, or services, as well as in its scope, which, in this case, would correspond to the entire life cycle [23].

The S-LCA will evaluate the social and socioeconomic aspects that will directly affect, both positively and negatively, the stakeholders during the life cycle of the product.

We define social impact as the consequence of the social relations (interactions) that we can find within the activity or that have been generated by it.

Within the social impacts, we find three dimensions:

- Behavior (associated with a specific behavior).

- Socioeconomic processes (effects after a socioeconomic decision).

- Capitals (human, social, or cultural).

These dimensions have complex relationships that must be carefully analyzed for the different social impacts emerging from their confluence, depending on aspects such as politics, economy, legislation, culture, and ethics.

Due to the constant increase of the older population in Western countries, the resources dedicated to the care of this population segment are progressively increasing.

On the other hand, the progressive decrease in physical activity as the age of individuals increases implies important impacts on the quality of life of individuals both on a physical and personal level and on the individual's own autonomy and self-esteem.

That is why the integration of physical exercise routines for the elderly, and especially for those who are in care institutions for the elderly or nursing homes, although it implies an economic cost derived from the activity itself, also implies an improvement in the living conditions of these people.

There is also another type of impact on the different stakeholders and agents involved. 


\subsection{Research Context}

This article evaluates the social and socioeconomic aspects of the implementation of physical exercise programs for the elderly with the aim of proposing a basis for applying this methodology as a system for evaluating the social impact of this activity. The study follows the UNEP/SETAC Guidelines for being the guides that define the applicable methodologies for life cycle analysis [25-27].

Therefore, this study will seek to analyze the impacts derived from the insertion of physical exercise programs for the elderly by analyzing the impacts generated on the different stakeholders and quantifying them, thus allowing us to carry out an in-depth analysis of the influence of the activity on each of these stakeholders and determining the areas in which this activity has the greatest influence, thus achieving a greater and better understanding of the activity.

\section{Materials and Methods}

\subsection{Objective and Scope}

The objective of this study is to evaluate the impact, both positive and negative, that the implementation of physical activity programs in routines for older people generates in the different stakeholders that are affected.

This will consider all the impacts generated by each of the activities necessary to carry out this exercise program, from its planning to its redesign through to its communication or its own execution.

\subsection{Functional Unit Definition}

For the present study, the functional unit is defined as "the process of caring for a nondependent older person in a specific entity specifically dedicated to this effect with a nominal capacity of 150 elderly and with the implementation of customized routines of 5 weekly hours of physical exercise for each senior".

Since it is a process, the differential inputs applicable to the care of the elderly, with and without the implementation of physical work routines, will be the same, with the only difference being the personal and material resources associated with physical performance.

According to those presented in this study, only the quantifiable aspects associated with the activity itself related to the implementation of physical exercise programs will be considered.

\subsection{Life Cycle Inventory}

The collection of data onsite allows us to evaluate the relationships between the organization and its stakeholders [28-30], including the local community, the local administration, the regional and central administration, the workers at the center, and, of course, the elderly themselves.

The primary data were collected through questionnaires created specifically for this study. The subcategories investigated were identified through the Ekener-Petersen methodological sheets [24].

We define the unitary process as those defined for the realization of the life cycle inventory.

The different phases of the life cycle will be divided into the following unitary processes, for which we define their significance based on the results obtained in the surveys carried out.

For the development of these questionnaires, the functional unit has been divided into unitary processes that we will define as those defined for the realization of the life cycle inventory.

The different phases of the life cycle will be divided into the following unitary processes, for which we define their significance based on the results obtained in the surveys carried out.

In this case, four phases are defined with their respective unitary processes described below.

Phase 1. Design and programming.

This phase includes the processes for the design and planning of the annual exercise program. It includes the following unitary processes: 
- Preliminary work. This unitary process includes previous studies of the needs, the population object of the program, the initial resources available, as well as any other aspects that are relevant for the development and implementation of the program. It is developed only in the initial phase of the program and does not extend to Phases 2, 3, and 4 of the program.

- Design. This unitary process includes the tasks of planning and design of the program activities adapted to each one of the users, including the planning of common activities as well as the planning of personalized activities. It is developed only in the initial phase of the program and does not extend to phases 2, 3, and 4 of the program.

- Programming of means and resources. This unitary process includes the establishment of means and resources foreseen for the realization of the activities designed in the previous points. It is developed continuously throughout the program until the end of Phase 3 of the program.

- Dissemination and training. It includes the set of activities aimed at communication and dissemination, both internally (own personnel) and externally (users, families, administration and other interest groups), as well as the training of the personnel of the care center for the elderly who do not actively participate in the activities, with respect to the implementation of the programs and their associated circumstances. The bulk of its activity is carried out in the initial phases of the program, although light activity is maintained during the program implementation and completion phase.

External assistance. An evaluation process carried out by an external entity to verify the suitability of the actions proposed and a context analysis of the program to justify and validate the achievement of the objectives set out in the program. This unitary process is developed only at the end of Phase 1 of design and programming.

Phase 2. Training and information program.

In this phase, the actions planned in Phase 1 are acquired and put into practice.

It includes the following unitary processes:

- Establishment of guidelines. In this unitary process, the key points and general objectives are defined, as well as the specific objectives of the program for each of the workers who will participate in the physical activity program for seniors. This unitary process is developed exclusively in the initial stage of Phase 2 of the training program.

- Training of therapists. This process includes the activities aimed at training current therapists and technicians in the execution of physical exercise programs for the elderly, including applicable techniques and safe environments. This unitary process is mostly developed in Phase 2, prior to the development of the physical exercise routines, although it also implies the existence of specific training during Phase 3.

- User information. This unitary process includes specific training prior to user training, with the aim of achieving adequate use of the program. This unitary process is developed in a specific way during Phase 2, before starting the implementation of the physical exercise routines for seniors.

Phase 3. Execution of the program.

Once the program has been designed and the resources for its execution have been consolidated, during Phase 3, the aforementioned program will be implemented, including the tasks of personalization and updating of the program to the users and their circumstances.

It includes the following unitary processes:

- Execution of routine exercise programs. This unitary process includes the execution of the exercise program with the users. It is specifically developed in Phase 3.

- Personalization. This unitary process includes the means and resources designated to personalize the programs during its development with the purpose of maximizing its efficiency and adaptation to the user. This process is parallel in its development to the unitary process designated for the accomplishment of routines of physical exercise in older people. 
- Updating of programs and methods. This unitary process includes the tasks designated to the update of programs and methods in search of their adaptation and optimization, according to internal or external factors. This unitary process of support is developed in parallel with the rest of the activities in Phase 3.

Phase 4. Program completion and system feedback.

During the development of the program and after its completion, data acquisition will be carried out that will allow the program to evolve and adapt to the needs of the users.

It includes the following unitary processes:

- Data collection. It consists of obtaining data from the system that will be subsequently processed with the aim of continuously improving and adapting the program. It is developed throughout Phases 3 and 4 .

- Data analysis and treatment. This unitary process seeks to process the data obtained in the previous point to allow the extraction of information regarding the program. It is developed only in Phase 4, once all the information has been obtained in the previous unitary process.

- Study and decision on improvements. This unitary process seeks, from the processed information obtained previously, to decide on potential improvements to the system and application and distribution of resources. It is developed only in Phase 4 from the information obtained in the previous processes.

- Data processing for feedback. This unitary process continuously processes the data from each program, comparing them with the objectives set, as well as with the comparable data from previous programs, allowing continuous feedback from the system for control and improvement. It is developed in a continuous way, along the four proposed phases.

Once the subcategories and the unitary processes to be evaluated were defined, they were modeled in questionnaires to be presented. The questionnaires were structured according to the methodological sheets and consisted of questions adapted to each of the actors involved. The results were related to the questionnaires developed and presented to the main stakeholders, as indicated below:

1. A questionnaire for the managers and employees of the institution.

2. A questionnaire for older service users.

The questionnaire for managers and workers consisted of four operational sections corresponding to the different phases of the life cycle and a common section, thanks to which the influence of the different stakeholders in the process was determined.

The common issues corresponded to three validation questions that contrasted the age of the individual, their current work situation, and their current performance with regard to the care of the elderly. These validation and control questions were used to determine those surveys that were randomly or incorrectly worded.

For the realization of this study, the service of care for elderly people, with an age of more than 65 years, in an institution with a capacity of 150 places, located in the town of Logroño, should be considered.

The questionnaire for the users of the service is similar to that for managers and technicians, except that the control and validation issues vary when considering the age of the user, his or her level of dependency, and the specific use of the service under study.

The questionnaires have been previously validated by a group of five experts in life cycle analysis, with the aim of ensuring adequate data collection as well as their suitability to the objectives of the proposed research. The data obtained have been validated and processed in the subsequent stages of the research. 


\subsection{Life Cycle Impact Assessment}

We define impact subcategories as socially relevant characteristics and represent areas of interest for those involved [23].

UNEP/SETAC proposes the next impact categories in a nonexhaustive manner, as we show in Table 6.

Table 6. Impact subcategories and stakeholder categories according to UNEP/SETAC.

\begin{tabular}{|c|c|}
\hline Impact Subcategory & Involved Categories \\
\hline $\begin{array}{c}\text { Freedom of Association } \\
\text { Child labor } \\
\text { Fair salary } \\
\text { Working hours } \\
\text { Forced labor } \\
\text { Equal opportunities/discrimination } \\
\text { Health and Safety } \\
\text { Social Benefits/Social Security }\end{array}$ & Workers \\
\hline $\begin{array}{c}\text { Health and Safety } \\
\text { Feedback mechanisms } \\
\text { Consumer Privacy } \\
\text { Transparency } \\
\text { Access to material resources } \\
\text { Access to intangible resources } \\
\text { End-of-life responsibility }\end{array}$ & Consumers/Users \\
\hline $\begin{array}{c}\text { Delocalization and migration } \\
\text { Cultural Heritage } \\
\text { Respect for indigenous rights } \\
\text { Safety and living conditions } \\
\text { Community engagement } \\
\text { Local employmentSecure living conditions }\end{array}$ & Local community \\
\hline $\begin{array}{l}\text { Public commitment to sustainability issues } \\
\text { Contribution to economic development } \\
\text { Prevention and mitigation of armed conflict } \\
\text { Technological development } \\
\text { Corruption }\end{array}$ & Society \\
\hline $\begin{array}{c}\text { Fair competition } \\
\text { Promotion of social responsibility } \\
\text { Respect of intellectual property rights } \\
\text { Suppliers relationship }\end{array}$ & Value chain actors \\
\hline
\end{tabular}

In this case, some of the proposed categories have been selected, while, due to the peculiarities of the case, some new categories are proposed.

The proposed impact subcategories are shown in Table 7.

Table 7. Proposed impact subcategories and involved categories.

\begin{tabular}{cc}
\hline Impact Subcategory & Involved Categories \\
\hline $\begin{array}{c}\text { Development of specialist work } \\
\text { Social Benefits/Social Security }\end{array}$ & Workers \\
\hline $\begin{array}{c}\text { Health and Safety } \\
\text { Development of self and personal autonomy } \\
\text { End-of-life responsibility }\end{array}$ & Consumers/Users \\
\hline SustainabilityImproved perception of services & Local community \\
\hline $\begin{array}{c}\text { Public commitment to sustainability issues } \\
\text { Contribution to economic } \\
\text { developmentImprovement of social } \\
\text { conditions of sensitive groups }\end{array}$ & Society \\
\hline Social responsibility promoción & Value chain actors \\
\hline
\end{tabular}

From the overlap of the selected impact categories with the unitary phases and processes, we obtain a matrix in which the points of confluence between both dimensions are indicated, as we reflect in Table 8. 
Table 8. Matrix of confluence of impact categories with selected unitary phases and processes.

\begin{tabular}{|c|c|c|c|c|c|c|c|c|c|c|c|c|}
\hline \multirow[b]{2}{*}{ Life Cycle Phase } & \multirow[b]{2}{*}{ Unitary Process } & \multicolumn{2}{|c|}{ Workers } & \multicolumn{3}{|c|}{ Consumers/Users } & \multicolumn{2}{|c|}{ Local Community } & \multicolumn{3}{|c|}{ Society } & \multirow{2}{*}{$\begin{array}{c}\begin{array}{c}\text { Value Chain } \\
\text { Actors }\end{array} \\
\begin{array}{c}\text { Social } \\
\text { Responsibility } \\
\text { Promotion }\end{array} \\
\end{array}$} \\
\hline & & $\begin{array}{l}\text { Development } \\
\text { of Specialist } \\
\text { Work }\end{array}$ & $\begin{array}{c}\text { Social } \\
\text { Benefit/Social } \\
\text { Security }\end{array}$ & $\begin{array}{l}\text { Health and } \\
\text { Safety }\end{array}$ & $\begin{array}{c}\text { Development of } \\
\text { Self and Personal } \\
\text { Autonomy }\end{array}$ & $\begin{array}{c}\text { End-life } \\
\text { Responsibility }\end{array}$ & Sustainability & $\begin{array}{l}\text { Improved } \\
\text { Perception of } \\
\text { Services }\end{array}$ & $\begin{array}{c}\text { Public } \\
\text { Commitment to } \\
\text { Sustainability }\end{array}$ & $\begin{array}{l}\text { Contribution } \\
\text { to Economic } \\
\text { Development }\end{array}$ & $\begin{array}{l}\text { Improvement of } \\
\text { Social Conditions } \\
\text { of Sensitive } \\
\text { Groups }\end{array}$ & \\
\hline \multirow{5}{*}{$\begin{array}{c}\text { Design and } \\
\text { programming }\end{array}$} & Preliminary work & $x$ & $x$ & & & & & $x$ & $x$ & $x$ & $x$ & \\
\hline & Program design & $x$ & $x$ & $x$ & $x$ & $x$ & & $x$ & & $x$ & $x$ & $x$ \\
\hline & Media and resource scheduling & $x$ & $x$ & & $x$ & $x$ & & & & $x$ & & \\
\hline & Dissemination/Training & & $x$ & $x$ & $x$ & $x$ & & $x$ & & & & \\
\hline & External assistance & $x$ & & & & & $x$ & & & $x$ & & \\
\hline \multirow{2}{*}{$\begin{array}{l}\text { Training/Information } \\
\text { program }\end{array}$} & Establishment of guidelines & & $\underset{x}{x}$ & & & & $x$ & & & $x$ & $x$ & $x$ \\
\hline & $\begin{array}{l}\text { Training for therapists } \\
\text { User information }\end{array}$ & $x$ & & $x$ & $x$ & $x$ & & $\hat{x}$ & & & $x$ & $x$ \\
\hline \multirow{3}{*}{$\begin{array}{c}\text { Program } \\
\text { implementation }\end{array}$} & Exercise programs and routines & & & $x$ & $x$ & $x$ & $x$ & $x$ & $x$ & & $x$ & $x$ \\
\hline & $\begin{array}{c}\text { Customization } \\
\end{array}$ & & & $x$ & $x$ & $x$ & $x$ & $x$ & & & $x$ & \\
\hline & $\begin{array}{l}\text { Updating programs and } \\
\text { methods }\end{array}$ & $\times$ & & $x$ & $x$ & $x$ & & $x$ & & & & \\
\hline \multirow{3}{*}{$\begin{array}{l}\text { Program } \\
\text { completion and } \\
\text { system feedback }\end{array}$} & $\begin{array}{c}\text { Data collection } \\
\text { Data analysis and processino }\end{array}$ & $\begin{array}{l}x \\
x\end{array}$ & & $\begin{array}{l}x \\
x\end{array}$ & & & $\begin{array}{l}x \\
x\end{array}$ & $\begin{array}{l}x \\
x\end{array}$ & & & $x$ & \\
\hline & $\begin{array}{l}\text { Data analysis and processing } \\
\text { Study and decision on }\end{array}$ & & & $x$ & $x$ & & & & & & $x$ & \\
\hline & $\begin{array}{l}\text { improvements } \\
\text { Data processing for feedback }\end{array}$ & $x$ & & & $\hat{x}$ & & $x$ & $x$ & & & $\hat{x}$ & \\
\hline
\end{tabular}


The results of the inventory should be classified and aggregated in relation to the impact and stakeholder categories, as indicated in the UNEP/SETAC guidelines (UNEP/SETAC, 2009).

\section{Results and Discussion}

An S-LCA model is used to analyze physical activity program implementation into old people's routines. For this study, the service of care for elderly people has been considered, with an age of more than 65 years, in an institution with a capacity of 150 places, located in the town of Logroño (La Rioja, Spain).

A total of 158 questionnaires were given out, 31 of which correspond to managers and carers and 127 questionnaires to users of the service, seeking to establish a population dispersion that reflects the fidelity of the sample to the reality of the users and providers of the service with respect to their age and sex.

If we look at the distribution by sex and age, as shown in Table 9, the population studied, both in the case of service providers and users of the service, is mainly female.

Table 9. Distribution of the population analyzed by sex.

\begin{tabular}{ccccc}
\hline & Managers and Caregivers & $\%$ & Service Users & $\%$ \\
\hline Men & 7 & $22.58 \%$ & 51 & $40.16 \%$ \\
\hline Women & 24 & $77.42 \%$ & 76 & $59.84 \%$ \\
\hline
\end{tabular}

Attending to the distribution of the population analyzed by age, shown in Table 10, it can be seen that the majority of carers and managers studied are in the age group between 26 and 40 years, with $64.52 \%$ of the total individuals surveyed, as shown in Table 10 .

Table 10. Distribution of the caregivers and managers surveyed by age.

\begin{tabular}{ccc}
\hline & Managers and Caregivers & $\%$ \\
\hline$<25$ years & 4 & $12.90 \%$ \\
\hline $26-40$ years & 20 & $64.52 \%$ \\
\hline $41-52$ years & 6 & $19.35 \%$ \\
\hline $53-65$ years & 1 & $3.23 \%$ \\
\hline$>65$ years & 0 & $0.00 \%$ \\
\hline
\end{tabular}

If we look at the age distribution of the service users, we can see how the population under $65 \%$ has a marginal influence on the study, while the age groups between 65 and 80 make up the majority of the individuals surveyed, as deduced from Table 11.

Table 11. Distribution of users surveyed by age.

\begin{tabular}{ccc}
\hline & Service Users & $\%$ \\
\hline$<65$ years & 2 & $1.57 \%$ \\
\hline $65-70$ years & 34 & $26.77 \%$ \\
\hline $70-75$ years & 48 & $37.80 \%$ \\
\hline $75-80$ years & 29 & $22.83 \%$ \\
\hline$>80$ years & 14 & $11.02 \%$ \\
\hline
\end{tabular}

The data obtained from the surveys were processed and assigned to each of the interest groups and activities defined in the previous sections. 
The design and validation section consisted of a total of 33 questions divided into all aspects to be considered.

The training and information program section consisted of a total of 16 questions divided into all the aspects to be considered.

The program implementation section consisted of a total of 22 questions divided into all the aspects to be considered.

Finally, the section on the completion of the program and feedback of the system consisted of a total of 20 questions divided among all the aspects to be considered.

Eleven additional questions were raised to obtain the remaining data and significance values needed.

These questionnaires have been previously validated by a panel of 5 experts in the development of LCA analyses to ensure their suitability for the proposed methodology and objectives.

From the data obtained, the significance levels for each of the unitary processes and the different impact categories reflected, respectively, in Tables 12 and 13 have been initially determined.

Table 12. Significance levels for each unitary process.

\begin{tabular}{ccc}
\hline Stakeholder & Impact Category & Significance \\
\hline \multirow{2}{*}{ Workers } & Development of specialist work & 3 \\
& Social Benefits/Social Security & 6 \\
\hline \multirow{2}{*}{ Consumers/Users } & Health and Safety & 4 \\
& Development of self and personal autonomy & 8 \\
\hline \multirow{2}{*}{ Local community } & End-life responsability & 7 \\
\hline \multirow{2}{*}{ Society } & Sustainability & 3 \\
& Improved perception of services & 6 \\
\hline Value chain actors & Public commitment to sustainability & 2 \\
\hline
\end{tabular}

Table 13. Significance levels for each impact category.

\begin{tabular}{ccc}
\hline Life Cycle Phase & Unitary Process & Significance \\
\hline \multirow{2}{*}{ Design and programming } & Preliminary work & 2 \\
& Program design & 10 \\
& Media and resource scheduling & 8 \\
& Dissemination/Training & 4 \\
Training/Information program & External assistance & 2 \\
\hline \multirow{2}{*}{ Program implementation } & Establishment of guidelines & 5 \\
& Training for therapists & 7 \\
& User information & 5 \\
\hline & Exercise programs and routines & 10 \\
Program completion and system feedback & Customization & 8 \\
& Updating programs and methods & 6 \\
\hline & Dtudy and decision on improvements & 8 \\
& Data Processing for Feedback & 9 \\
\hline
\end{tabular}

These levels of significance will allow the results obtained in the different questions posed in the surveys to be weighted.

From the data obtained from the surveys, the values associated with each impact category and unitary process are obtained. 
A calculation matrix according to impact categories and unitary phases and processes for the design and programming phase is shown in Table 14.

From the data described in Table 14, it can be seen that program design shows the highest unweighted values of the entire matrix at its intersection with development of specialist work and the improvement of social conditions of sensitive groups.

A calculation matrix according to impact categories and unitary phases and processes for the training and information program phase is shown in Table 15.

From the data described in Table 14, it can be seen that user information and training for therapists shows the highest unweighted values at its intersection with the development of self and personal and development of specialist work, respectively.

A calculation matrix according to impact categories and unitary phases and processes for the program implementation phase is shown in Table 16.

From the data described in Table 15, it can be seen that exercise programs and routines, at its intersection with health and safety and customization and at its intersection with improved perception of services and improvement of social conditions of sensitive groups shows the highest unweighted values at its intersection with development of self and personal and development of specialist work, respectively.

Finally, a calculation matrix according to impact categories and unitary phases and processes for program completion and system feedback phase is shown in Table 16.

From the data described in Table 17, it can be seen that data processing for feedback at its intersection with improvement of social conditions of sensitive groups shows the highest unweighted values.

The analysis of the impacts for each category of impact, as we described above, shows that the main beneficiaries of the impacts derived from this activity will be the users/consumers, which is foreseeable, given the nature of the service itself.

It is representative, however, to appreciate how both the local community and the State are recipients of positive impacts in a remarkable way and far above other categories such as workers, who, beforehand, would seem to be the focus of such impacts.

From the sum of the values obtained in the previous sections for each subcategory, the index for each impact subcategory is obtained.

Considering significance as a weighting factor, we calculated the adjusted impact index for each subcategory.

From the sum of the adjusted indices for all the subcategories that make up a category, the index per impact category is obtained.

Table 18 shows all the weighted indices for each subcategory and impact category.

From Table 18 data, it can be deduced that the main stakeholder affected by the impacts derived from the insertion of physical activity programs are the users, as might seem obvious.

The impact on the development of self-esteem and personal autonomy implies much greater repercussions than those associated with health or responsibility at the end of life.

The impact on the local community is also very important and is mainly associated with the improvement of the perception of the services. This subcategory is the one that, after the development of self-esteem and personal autonomy, implies the greatest impact.

The improvement of social conditions of sensitive groups also has a considerable impact.

Finally, the impacts on workers and especially on the value chain, are much less than those associated with the rest of the stakeholders. 
Table 14. Design and programming phase unweighted impacts.

\begin{tabular}{|c|c|c|c|c|c|c|c|c|c|c|c|}
\hline & $\begin{array}{l}\text { Development of } \\
\text { Specialist Work }\end{array}$ & $\begin{array}{c}\text { Social } \\
\text { Benefits/Social } \\
\text { Security }\end{array}$ & $\begin{array}{l}\text { Health and } \\
\text { Safety }\end{array}$ & $\begin{array}{l}\text { Development of } \\
\text { self and Personal } \\
\text { Autonomy }\end{array}$ & $\begin{array}{l}\text { Responsibility } \\
\text { at the End of } \\
\text { Life }\end{array}$ & Sustainability & $\begin{array}{l}\text { Improved } \\
\text { Perception of } \\
\text { Services }\end{array}$ & $\begin{array}{c}\text { Public } \\
\text { Commitment to } \\
\text { Sustainability }\end{array}$ & $\begin{array}{l}\text { Contribution to } \\
\text { Economic } \\
\text { Development }\end{array}$ & $\begin{array}{c}\text { Improvement of } \\
\text { Social } \\
\text { Conditions of } \\
\text { Sensitive } \\
\text { Groups } \\
\end{array}$ & $\begin{array}{c}\text { Social } \\
\text { Responsibility } \\
\text { Promotion }\end{array}$ \\
\hline Preliminary work & 4 & 2 & & & & & 2 & 2 & 1 & 1 & \\
\hline Program design & 6 & 2 & 2 & 2 & 1 & & 4 & & 1 & 7 & 2 \\
\hline $\begin{array}{l}\text { Media and resource } \\
\text { scheduling }\end{array}$ & 4 & 1 & & 3 & 1 & & & & 2 & & \\
\hline Dissemination/Training & & 1 & 2 & 2 & 1 & & 2 & & & & \\
\hline External assistance & 2 & & & & & 1 & & & 4 & & \\
\hline
\end{tabular}

Table 15. Training and information program phase unweighted impacts.

\begin{tabular}{|c|c|c|c|c|c|c|c|c|c|c|c|}
\hline & $\begin{array}{l}\text { Development of } \\
\text { Specialist Work }\end{array}$ & $\begin{array}{c}\text { Social } \\
\text { Benefits/Social } \\
\text { Security }\end{array}$ & $\begin{array}{l}\text { Health and } \\
\text { Safety }\end{array}$ & $\begin{array}{l}\text { Development of } \\
\text { self and Personal } \\
\text { Autonomy }\end{array}$ & $\begin{array}{l}\text { Responsibility } \\
\text { at the End of } \\
\text { Life }\end{array}$ & Sustainability & $\begin{array}{l}\text { Improved } \\
\text { Perception of } \\
\text { Services }\end{array}$ & $\begin{array}{c}\text { Public } \\
\text { Commitment to } \\
\text { Sustainability }\end{array}$ & $\begin{array}{l}\text { Contribution to } \\
\text { Economic } \\
\text { Development }\end{array}$ & $\begin{array}{l}\text { Improvement of } \\
\text { Social } \\
\text { Conditions of } \\
\text { Sensitive } \\
\text { Groups } \\
\end{array}$ & $\begin{array}{c}\text { Social } \\
\text { Responsibility } \\
\text { Promotion }\end{array}$ \\
\hline $\begin{array}{l}\text { Establishment of } \\
\text { guidelines }\end{array}$ & & 1 & & & & 1 & & & 1 & 1 & \\
\hline $\begin{array}{l}\text { Training for } \\
\text { therapists }\end{array}$ & 5 & 3 & & & & & 4 & & & & 3 \\
\hline User information & & & 2 & 6 & 4 & & 3 & & & 2 & \\
\hline
\end{tabular}

Table 16. Program implementation phase unweighted impacts.

\begin{tabular}{|c|c|c|c|c|c|c|c|c|c|c|c|}
\hline & $\begin{array}{l}\text { Development of } \\
\text { Specialist Work }\end{array}$ & $\begin{array}{c}\text { Social } \\
\text { Benefits/Social } \\
\text { Security }\end{array}$ & $\begin{array}{l}\text { Health and } \\
\text { Safety }\end{array}$ & $\begin{array}{c}\text { Development of } \\
\text { self and Personal } \\
\text { Autonomy }\end{array}$ & $\begin{array}{l}\text { Responsibility } \\
\text { at the End of } \\
\text { Life }\end{array}$ & Sustainability & $\begin{array}{l}\text { Improved } \\
\text { Perception of } \\
\text { Services }\end{array}$ & $\begin{array}{c}\text { Public } \\
\text { Commitment to } \\
\text { Sustainability }\end{array}$ & $\begin{array}{c}\text { Contribution to } \\
\text { Economic } \\
\text { Development }\end{array}$ & $\begin{array}{c}\text { Improvement of } \\
\text { Social } \\
\text { Conditions of } \\
\text { Sensitive } \\
\text { Groups } \\
\end{array}$ & $\begin{array}{c}\text { Social } \\
\text { Responsibility } \\
\text { Promotion }\end{array}$ \\
\hline $\begin{array}{l}\text { Exercise programs } \\
\text { and routines }\end{array}$ & & & 7 & 5 & 6 & 4 & 6 & 3 & & 4 & 3 \\
\hline Customization & & & 4 & 5 & 6 & & 7 & & & 7 & \\
\hline $\begin{array}{l}\text { Updating programs } \\
\text { and methods }\end{array}$ & 2 & & 2 & 3 & 1 & & 1 & & & & \\
\hline
\end{tabular}


Table 17. Program completion and system feedback.

\begin{tabular}{|c|c|c|c|c|c|c|c|c|c|c|c|}
\hline & $\begin{array}{l}\text { Development of } \\
\text { Specialist Work }\end{array}$ & $\begin{array}{c}\text { Social } \\
\text { Benefits/Social } \\
\text { Security }\end{array}$ & $\begin{array}{l}\text { Health and } \\
\text { Safety }\end{array}$ & $\begin{array}{l}\text { Development of } \\
\text { self and Personal } \\
\text { Autonomy }\end{array}$ & $\begin{array}{l}\text { Responsibility } \\
\text { at the End of } \\
\text { Life }\end{array}$ & Sustainability & $\begin{array}{l}\text { Improved } \\
\text { Perception of } \\
\text { Services }\end{array}$ & $\begin{array}{c}\text { Public } \\
\text { Commitment to } \\
\text { Sustainability }\end{array}$ & $\begin{array}{l}\text { Contribution to } \\
\text { Economic } \\
\text { Development }\end{array}$ & $\begin{array}{l}\text { Improvement of } \\
\text { Social } \\
\text { Conditions of } \\
\text { Sensitive } \\
\text { Groups }\end{array}$ & $\begin{array}{c}\text { Social } \\
\text { Responsibility } \\
\text { Promotion }\end{array}$ \\
\hline Data collection & 3 & & 2 & & & 2 & 4 & & & & \\
\hline $\begin{array}{l}\text { Data analysis and } \\
\text { processing }\end{array}$ & 1 & & 2 & & & & 1 & & & & \\
\hline $\begin{array}{l}\text { Study and decision } \\
\text { on improvements }\end{array}$ & & & & 2 & & & & & & 2 & \\
\hline $\begin{array}{l}\text { Data Processing for } \\
\text { Feedback }\end{array}$ & 2 & & & 2 & & 1 & 4 & & & 5 & \\
\hline
\end{tabular}

Table 18. Social life cycle analysis (S-LCA) stakeholder results.

\begin{tabular}{|c|c|c|c|c|c|c|c|c|c|c|c|}
\hline & $\begin{array}{l}\text { Development of } \\
\text { Specialist Work }\end{array}$ & $\begin{array}{c}\text { Social } \\
\text { Benefits/Social } \\
\text { Security }\end{array}$ & $\begin{array}{l}\text { Health and } \\
\text { Safety }\end{array}$ & $\begin{array}{c}\text { Development of } \\
\text { self and Personal } \\
\text { Autonomy }\end{array}$ & $\begin{array}{l}\text { Responsibility } \\
\text { at the End of } \\
\text { Life }\end{array}$ & Sustainability & $\begin{array}{l}\text { Improved } \\
\text { Perception of } \\
\text { Services }\end{array}$ & $\begin{array}{c}\text { Public } \\
\text { Commitment to } \\
\text { Sustainability }\end{array}$ & $\begin{array}{c}\text { Contribution to } \\
\text { Economic } \\
\text { Development }\end{array}$ & $\begin{array}{l}\text { Improvement of } \\
\text { Social } \\
\text { Conditions of } \\
\text { Sensitive } \\
\text { Groups } \\
\end{array}$ & $\begin{array}{c}\text { Social } \\
\text { Responsibility } \\
\text { Promotion }\end{array}$ \\
\hline $\begin{array}{l}\text { Index by impact } \\
\text { subcategory }\end{array}$ & 29 & 10 & 23 & 30 & 20 & 9 & 38 & 5 & 9 & 30 & 8 \\
\hline $\begin{array}{l}\text { Index by adjusted } \\
\text { impact subcategory }\end{array}$ & 1.92 & 1.08 & 2 & 5.12 & 2.94 & 0.54 & 4.68 & 0.24 & 0.4 & 3.6 & 0.48 \\
\hline $\begin{array}{l}\text { Index by impact } \\
\text { category }\end{array}$ & \multicolumn{2}{|c|}{3} & \multicolumn{3}{|c|}{10,06} & \multicolumn{2}{|c|}{5,22} & & 4,24 & & 0,48 \\
\hline
\end{tabular}


From the sum of the values obtained in the previous sections for each unitary process, the index for each unitary process is obtained.

Considering significance as a weighting factor, we calculated the adjusted impact index for each unitary process.

From the sum of the adjusted indices for all the unitary processes that make up a process, the index per process is obtained.

Table 19 shows all the weighted indices for each life cycle phase and unitary process.

Table 19. S-LCA life cycle phase and unitary process results.

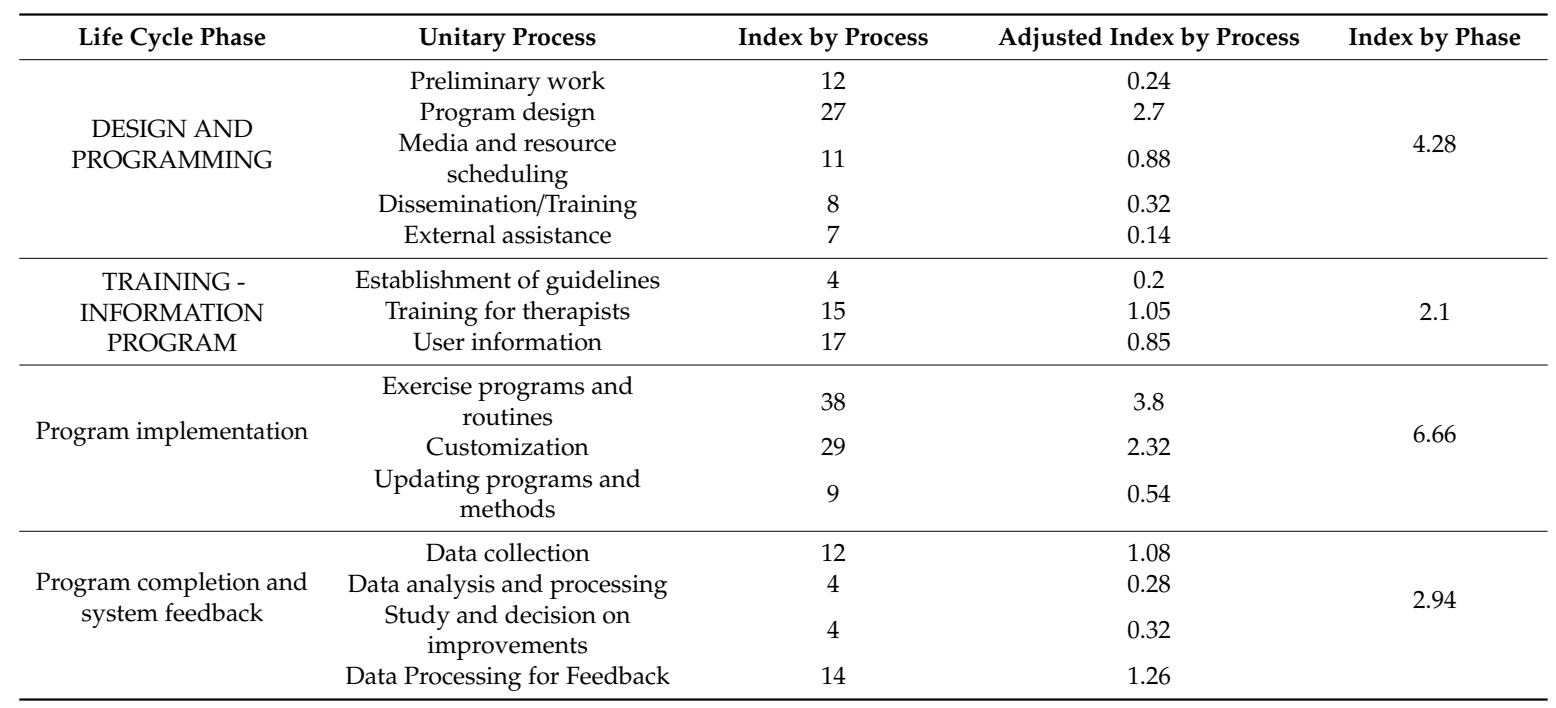

From the analysis of these data, it can deduce that the impact analysis for each phase of the life cycle reflects how the execution of the program takes on a predominant position while the training and information program and the program completion and feedback actions are those with the least impact.

A detailed analysis of the impact subcategories shows how the improvement of the social conditions of sensitive groups (the elderly), the improvement in the perception of services, and the development of self-esteem and personal autonomy are the most representative factors and those that will have the greatest impact on the population under study, far beyond the results of the application of exercise routines on their own health or on social responsibility.

If we analyze the impacts generated for each of the phases and activities proposed, it can be clearly seen how the implementation phase will have the greatest impact on users.

However, the influence of the programming and design phase is greater than the establishment of the training and information program, and on the completion of the program and feedback, so the impacts will be much more associated with this design phase than with the other activities proposed.

\section{Conclusions}

This article presents an S-LCA of physical activity program implementation into old people's routines.

A proposal to apply the S-LCA methodology for the implementation of physical activity programs in routines for older people was developed, allowing a complete evaluation of the impact of such activities. The guidelines established by UNEP/SEPAC were followed to obtain impact results for the different categories and stakeholders.

Looking at the results obtained, it must be stressed that all the impacts generated were positive. Even those associated with economic development and sustainability imply positive impacts since the cost of implementing these programs is perceived as lower than the indirect cost reduction derived from their implementation. 
Based on the analysis of the inventory and social impacts, it is concluded that the processes with the greatest impact are program implementation followed by design and programming.

The program implementation phase has two unitary processes with a high impact level. Exercise program execution is the unitary process with the highest impact level of every unitary process studied. The customization unitary process also has a high level of impact, although it does not reach the levels of the previous unitary process.

The design and programming phase also has a great positive impact, although it is lower than the program implementation phase. Although most of the unitary processes that make up this phase have low impacts, the high impact of the unitary design process is noteworthy.

On the other hand, the phases with the least impact are training-information program and program completion and system feedback. Especially noteworthy are the low levels of impact of the unitary processes associated with the unitary process of external assistance.

As expected, the impacts associated with those unitary processes aimed at program implementation, design and development, and customization are those that have the most impact.

The analysis of the impact on the different stakeholders allows us to determine that, as expected, the users are the most affected by the positive impact of the implementation of the exercise program on the elderly.

Especially decisive is the impact of the development of self-esteem and personal autonomy over others that, at first, seemed more like the user's own health or end life responsibility.

This is because the old people targeted by the physical exercise program prioritize the quality of life and personal autonomy over longevity or physical ailments.

Throughout this article, a proposal has been made to apply the S-LCA methodology for the implementation of physical activity programs in routines for older people, allowing a complete evaluation of the impact of such activities.

Some of the conclusions that can be drawn from the study carried out are the following:

- The model proposed and based on surveys gives coherent results that are in line with reality.

- The results obtained can be adjusted, in most cases, to cause and effect relationships.

- The results are consistent despite having started from a simple data inventory.

- The limited availability of data has meant that the differences between factors with high impacts and those with low impacts are especially notable, so the possibility of a certain bias should be considered, which should be corrected by accessing a larger population of respondents.

- The methodology appears to be an interesting tool that can be fully applied to the proposed hypothesis.

\section{Future Outlook and Possibilities for Improvement}

Based on the results obtained, some aspects to be considered in order to optimize the proposed methodology and its results are deduced.

- The possibility of accessing a real and updated inventory would considerably improve the perception and precision of this study.

- The amount of data obtained and the wealth of the population has turned out to be a determining factor, so accessing a larger population would considerably improve the precision and variability of the results.

- In order to achieve more complete results, not only caregivers and users should be considered, but also non-users of different ages and social strata, non-users with a direct relationship with users (e.g., relatives), members of the public administration, and professionals in these areas should be interviewed.

- The comparative study of the evolution of S-LCA over several years, as well as the relative impact between different activities, would yield very interesting data regarding the proposals and destination of resources. 
Author Contributions: Conceptualization, F.J.F.-M. and L.Á.-K.; data curation, F.J.F.-M., L.Á.-K., and A.S.-T.L.; formal analysis, A.S.-T.L. and J.L.G.-A.; investigation: F.J.F.-M. and L.Á.-K.; methodology, J.L.G.-A. and L.Á.-K.; resources, L.Á.-K. and A.S.-T.L.; validation, F.J.F.-M. and J.L.G.-A.; visualization, A.S.-T.L.; writing-original draft, F.J.F.-M., L.Á.-K., and J.L.G.-A.; writing—review and editing, A.S.-T.L. and J.L.G.-A. All authors have read and agreed to the published version of the manuscript.

Funding: This research received no external funding.

Acknowledgments: The authors appreciate the collaboration from institutions, service users, managers and workers, engineers, technicians, and other people that responded to our survey, providing information for this paper.

Conflicts of Interest: The authors declare that there is no conflict of interest. Since there were no funders, they had no role in the design of the study, in the collection, analysis, or interpretation of the data, in the writing of the manuscript, or in the decision to publish the results.

\section{References}

1. Cuadrado, P. Evolución reciente de la población residente en España. In Evolución Reciente y Proyecciones de la Población en España; Banco de España: Madrid, Spain, 2019.

2. Pont, P. Tercera Edad, Actividad Física y Salud, 2nd ed.; Paidotribo: Barcelona, Spain, 2010.

3. Jerome, G.J.; Glass, T.; Mielke, M.M.; Xue, Q.-L.; Andersen, R.E.; Fried, L.P. Physical activity participation by presence and type of functional deficits in older women: The women's health and aging studies. J. Gerontol. Ser. A Biol. Sci. Med. Sci. 2006, 61, 1171-1176. [CrossRef] [PubMed]

4. Onetti, W.; Álvarez-Kurogi, L.; Castillo-Rodríguez, A. Adherence to the Mediterranean diet pattern and self-concept in adolescents. Nutr. Hosp. 2019, 36, 658-664.

5. Berger, P.; Luckmann, T. La Construcción Social de la Realidad; Amorrortu Editores España SL: Buenos Aires, Argentina, 1993.

6. O'Connor, P.J.; Aenchbacher, L.E.; Dishman, R. Physical activity and depression in the elderly. J. Aging Phys. Act. 1993, 1, 34-58. [CrossRef]

7. Jiménez, B.M.; Gómez, C.X. Evaluación de la calidad de vida. In Manual de Evaluación en Psicología Clínica y de la Salud; Buela, A., Ed.; Siglo XXI de España Editores, S.A.: Madrid, España, 1996; Volume Siglo XXI, pp. 1045-1070.

8. Velez, R.R.; Alban, C.A.L.; Reina, H.R.T.; Idarraga, M.; Gensini, F.G. Beneficios percibidos de un grupo de mujeres en climaterio incorporadas a un programa de actividad física terapéutica. Apunts Med. l'Esport 2008, 43, 14-23. [CrossRef]

9. Gutiérrez-Valencia, M.; Herce, P.A.; Lacalle-Fabo, E.; Escámez, B.C.; Cedeno-Veloz, B.; Martínez-Velilla, N. Prevalencia de polifarmacia y factores asociados en adultos mayores en España: Datos de la Encuesta Nacional de Salud 2017. Med. Clínica 2019, 153, 141-150. [CrossRef] [PubMed]

10. María Jesús Vidal Domínguez, M.J.; Labeaga Azcona, J.M.; Casado Durandez, P.; Madrigal Muñoz, A.; López Doblas, J.; Montero Navarro, A.; Meil Landwerlin, G.; IMSERSO. Informe 2016. In Las Personas Mayores en España. Datos Estadísticos Estatales y por Comunidades Autónomas; Ministerio de Sanidad, Servicios Sociales e Igualdad Secretaría de Estado de Servicios Sociales e Igualdad Instituto de Mayores y Servicios Sociales (IMSERSO): Madrid, España, 2017.

11. Martínez, E.; Latorre-Biel, J.-I.; Jiménez-Macías, E.; Sanz, F.; Blanco-Fernandez, J. Life cycle assessment of a wind farm repowering process. Renew. Sustain. Energy Rev. 2018, 93, 260-271. [CrossRef]

12. García-Alcaraz, J.L.; Montalvo, F.J.F.; Cámara, E.M.; De La Parte, M.M.P.; Jiménez-Macías, E.; Blanco-Fernandez, J. Economic-environmental impact analysis of alternative systems for red wine ageing in re-used barrels. J. Clean. Prod. 2020, 244, 118783. [CrossRef]

13. Flor, F.J.; Leiva, F.J.; García-Alcaraz, J.L.; Martínez, E.; Jiménez-Macías, E.; Blanco-Fernandez, J. Environmental impact of wine aging process in oak barrels in wineries of La Rioja (Spain). Am. J. Enol. Vitic. 2018, 69, 302-306. [CrossRef]

14. Cámara, E.M.; Blanco-Fernandez, J.; Jiménez-Macías, E.; Muro, J.C.S.-D.; Sanz-Adan, F. Comparative evaluation of life cycle impact assessment software tools through a wind turbine case study. Renew. Energy 2015, 74, 237-246. [CrossRef]

15. Leiva, F.; Saenz-Díez, J.; Martinez, E.; Jiménez-Macías, E.; Blanco-Fernandez, J. Environmental impact of Agaricus bisporus mycelium production. Agric. Syst. 2015, 138, 38-45. [CrossRef] 
16. Azzouz, A.; Borchers, M.; Moreira, J.; Mavrogianni, A. Life cycle assessment of energy conservation measures during early stage office building design: A case study in London, UK. Energy Build. 2017, 139, 547-568. [CrossRef]

17. Notarnicola, B.; Hayashi, K.; Curran, M.A.; Huisingh, D. Progress in working towards a more sustainable agri-food industry. J. Clean. Prod. 2012, 28, 1-8. [CrossRef]

18. Yang, Y.; Campbell, J.E. Improving attributional life cycle assessment for decision support: The case of local food in sustainable design. J. Clean. Prod. 2017, 145, 361-366. [CrossRef]

19. Angelo, A.C.M.; Saraiva, A.B.; Clímaco, J.C.N.; Infante, C.E.; Valle, R. Life cycle assessment and multi-criteria decision analysis: Selection of a strategy for domestic food waste management in Rio de Janeiro. J. Clean. Prod. 2017, 143, 744-756. [CrossRef]

20. Cespi, D.; Beach, E.; Swarr, T.E.; Passarini, F.; Vassura, I.; Dunn, P.J.; Anastas, P. Life cycle inventory improvement in the pharmaceutical sector: Assessment of the sustainability combining PMI and LCA tools. Green Chem. 2015, 17, 3390-3400. [CrossRef]

21. Falcone, G.; Strano, A.; Stillitano, T.; De Luca, A.I.; Iofrida, N.; Gulisano, G. Integrated sustainability appraisal of wine-growing management systems through LCA and LCC Methodologies. Chem. Eng. Trans. 2015, 44, 223-228.

22. Wang, X.; Chen, Y.; Sui, P.; Gao, W.; Qin, F.; Wu, X.; Xiong, J. Efficiency and sustainability analysis of biogas and electricity production from a large-scale biogas project in China: An emergy evaluation based on LCA. J. Clean. Prod. 2014, 65, 234-245. [CrossRef]

23. Neugebauer, S.; Traverso, M.; Scheumann, R.; Chang, Y.-J.; Wolf, K.; Finkbeiner, M. Impact pathways to address social well-being and social justice in SLCA—Fair wage and level of education. Sustainability 2014, 6, 4839-4857. [CrossRef]

24. Arcese, G.; Lucchetti, M.C.; Merli, R. Social life cycle assessment as a management tool: Methodology for application in tourism. Sustainability 2013, 5, 3275-3287. [CrossRef]

25. Benoît, C.; Norris, G.A.; Valdivia, S.; Ciroth, A.; Moberg, Å.; Bos, U.; Prakash, S.; Ugaya, C.; Beck, T. The guidelines for social life cycle assessment of products: Just in time! Int. J. Life Cycle Assess. 2010, 15, 156-163. [CrossRef]

26. Rivera-Huerta, A.; Rubio, M.; Padilla-Rivera, A.; Güereca, L.P. Social sustainability assessment in livestock production: A social life cycle assessment approach. Sustainability 2019, 11, 4419. [CrossRef]

27. Tsalidis, G.A.; Korevaar, G. Social Life Cycle Assessment of brine treatment in the process industry: A consequential approach case study. Sustainability 2019, 11, 5945. [CrossRef]

28. Ekener-Petersen, E.; Finnveden, G.; Ekener, E. Potential hotspots identified by social LCA-Part 1: A case study of a laptop computer. Int. J. Life Cycle Assess. 2012, 18, 127-143. [CrossRef]

29. D’Eusanio, M.; Serreli, M.; Petti, L. Social life-cycle assessment of a piece of jewellery. Emphasis on the local community. Resources 2019, 8, 158. [CrossRef]

30. Parent, J.; Cucuzzella, C.; Réveret, J.-P. Impact assessment in SLCA: Sorting the sLCIA methods according to their outcomes. Int. J. Life Cycle Assess. 2010, 15, 164-171. [CrossRef]

(C) 2020 by the authors. Licensee MDPI, Basel, Switzerland. This article is an open access article distributed under the terms and conditions of the Creative Commons Attribution (CC BY) license (http://creativecommons.org/licenses/by/4.0/). 